\title{
PEMBANGUNAN SANITASI TEMPAT MCK KOMUNAL DI DESA URUG, BOGOR, JAWA BARAT
}

\author{
Dyah Nurwidyaningrum $^{1}$, Andika Pradiptiya ${ }^{2}$, Rinawati $^{3}$ \\ ${ }^{123}$ Jurusan Teknik Sipil, Politeknik Negeri Jakarta \\ nurwidyaningrum@yahoo.com
}

\begin{abstract}
Abstrak
Desa Urug memiliki potensi sebagai dentinasi wisata budaya (cultural heritage) dan aktif melakukan kegiatan ritual adat setiap tahun yang mengundang banyak turis mancanegara. Saat ini, kondisi tempat mandi, cuci, dan kakus (MCK) komunal di Desa Urug belum mencukupi kebutuhan warganya apalagi untuk turis yang berkunjung. Sanitasi tempat MCK di Desa Urug sangat dibutuhkan karena mulai terjadi degradasi lingkungan di daerah desa yang padat dan sebagian besar warga tidak memiliki MCK pribadi. Tujuan dari pengabdian ini adalah untuk menghasilkan bangunan MCK dan sanitasi pelengkap yang mendorong cara hidup sehat dan tidak mencemarkan lingkungan di Desa urug dan sekitarnya. Metode yang digunakan untuk menyelesaikan persoalan ini adalah pembangunan perlengkapan sanitasi dan MCK komunal yang terpadu dengan tempat MCK yang sedang dibangun oleh pemerintah Desa Urug. Hasil dari pengabdian ini adalah tempat MCK yang lengkap dengan sistem sanitasi sehingga warga terhindar dari penyakit dan pencemaran lingkungan. MCK ini ditempatkan berada di tepi sungai dengan pelengkap sanitasi di bawahnya, teras MCK menghadap ke arah permukiman warga, dengan demikian warga dapat langsung mengawasi penggunaannya dan membersihkan dengan cepat. Standar MCK yang dilaksanakan berdasarkan standar SNI. Keberadaan MCK dengan sanitasi ini menjadi bagian prasarana kewisataan Desa Urug. Selain itu hasil dari pengabdian ini sebagai model contoh untuk diterapkan pada tempat MCK lain di Desa Urug tersebut.
\end{abstract}

Kata kunci: MCK komunal, perlengkapan sanitasi, kampung wisata, degradasi lingkungan

\begin{abstract}
The village of Urug has the potential as a destination of cultural heritage tourism and active in conducting traditional ritual activities every year that invite many foreign tourists. At present, the condition of communal bathing, washing and toilet facilities (MCK) in the village of Urug is not sufficient for the needs of its residents, especially for tourists who visit. Sanitation of MCK facilities in Urug Village is densely needed because environmental degradation has begun in a crowded village environment and most residents do not have private MCK. The purpose of this service is to produce complementary sanitation building that encourages healthy ways of life and does not pollute the environment in the village of Urug and its surroundings. The method used to solve this problem is the construction of sanitation equipment that is integrated with the MCK site being built by the Urug Village government. The results of this service are sanitary facilities that are complete with sanitation systems so that residents avoid diseases and environmental pollution. This MCK is located on the banks of the river with complementary sanitation below it, the terrace of the MCK faces the direction of the residents' settlement, thus residents can immediately monitor their use and clean up quickly. MCK standards are implemented based on SNI standards. The presence of sanitation facilities is part of the Urug Village tourism infrastructure. In addition, the results of this service as an example model to be applied to other MCK locations in the village of Urug.
\end{abstract}


Keywords: Comunal MCK, complementary sanitation, tourism village, environmental degradation

\section{Pendahuluan}

Observasi pendahuluan di Desa Urug menunjukkan bahwa sangat sedikit keluarga yang memiliki kamar mandi dan kakus bahkan fasilitas umum seperti mushola juga tidak tersedia kamar mandi dan kakus. Warga yang memiliki kamar mandi dan kakus adalah keluarga yang mempunyai pendapatan rata-rata lebih tinggi dari keluarga lainnya. Kondisi kamar mandi dan kakus yang dimiliki keluarga tersebut belum semuanya dilengkapi sarana sanitasi seperti septik tank sehingga dapat menyebabkan pencemaran air dan tanah. Perilaku yang baik di Desa Urug ini adalah keluarga yang memiliki kakus memperbolehkan warga lainnya untuk dapat menggunakan kakus tersebut secara bersama. Hal ini bisa terjadi karena padadasarnya mereka berasal dari satu keturunan, yaitu masih keturunan keluarga raja Pejajaran dan perilaku dasar etnis Sunda yang positif (CSG, 2016). Penelitian sebelumnya menunjukkan perilaku kebersamaan di masyarakat Sunda cukup erat dan mereka cenderung rajin memelihara kebersihan lingkungan di sekitar tempat tinggal (Nurwidyaningrum, 2014), ini adalah potensi yang mendukung untuk pemberdayaan bangunan komunal.

Desa urug sebagai salah satu destinasi wisata membutuhkan prasarana pelengkap seperti kamar mandi dan kakus. Turis yang selama ini berkunjung umumnya menginap di rumah warga karena jauhnya lokasi desa dari jalan umum. Ketersediaan MCK sangat membantu warga menerima kedatangan para turis selain memenuhi kebutuhan warga. Ini akan meningkatkan citra wisata dan motivasi warga untuk mengelola wisata. Berdasarkan temuan sebelumnya, motivasi dan citra destinasi merupakan variabel yang sangat penting untuk tujuan kunjungan kembali wisata (Pratminingsih, 2014) dan elemen utaman untuk pengembangan wisata (Heston, 2007). Selain itu dengan meningkatnya prasarana dan kunjungan wisata akan meningkatkan pendapatan masyarakat Desa Urug. Dengan manfaat ini, masyarakat akan mendukung program pemerintah dalam pengembangan wisata berbasis cultural heritage (warisan budaya).

Sebagian besar masyarakat desa Urug memanfaatkan mata air yang mengalir ke sungai sebagai sumber utama air bersih namun mereka yang tinggal dekat sungai cenderung mandi, membuang hajat dan mencuci di sungai yang berada di tengah kawasan. Dengan padatnya permukiman di Desa Urug, kondisi sungai yang digunakan semakin kering dan mulai tercemar. Menurut penelitian sebelumnya, daerah tepi sungai yang dilindungi dapat menjadikannya sebagai sumber air, transportasi air dan tujuan wisata air. Saat ini, pariwisata berbasis air semakin populer bagi turis. Penduduk setempat harus diberi pemahaman tentang pentingnya pariwisata didasarkan pada lingkungan sungai dan halhal yang perlu dilakukan untuk mendukung kegiatan ini sehingga kebersihan sungai harus dijaga dan dilestarikan (Fachrudin, 2016).

Berdasarkan penjelasan di atas kebutuhan akan MCK dengan pelengkap sanitasi sangat dibutuhkan masyarakat Desa Urug untuk memenuhi kebutuhan dasar dan kualitas kesehatan masyarakatnya. Selain itu untuk melengkapi prasarana wisata yang berimplikasi kepada kenaikan kesejahteraan. Dampak kualitas lingkungan juga dapat dipertahankan dan diharapkan juga memperbaiki pola perilaku warga untuk memelihara sungai dan mengembangkan wisata yang berbasis sungai tersebut. 


\section{Metode}

Desa Urug berada pada lintang $6,6^{\circ} \mathrm{LS}$ dan bujur $106,5^{\circ}$ BT. Pemerintahan administratif mencakup seluruh wilayah desa termasuk Kampung Adat Urug. Desa Urug mempunyai topografi perbukitan dan berada di lembah tepi Sungai Cidurian. Jarak tempuh Desa Urug dari pusat Kecamatan Sukajaya sekitar 9 km. Dari pusat Pemerintahan Kabupaten Bogor untuk mencapai Desa Urug jaraknya sekitar $65 \mathrm{~km}$. Luas Desa Urug lebih kurang 400,5 hektar dengan peruntukan 368 hektar sawah dan ladang, 28 hektar untuk pemukiman dan perumahan, bangunan umum 0,5 hektar, dan 4 hektar untuk pemakaman. Batas wilayah sebelah utara berbatasan dengan Desa Harkatjaya, sebelah timur berbatasan dengan Desa Nanggung, sebelah selatan berbatasan dengan Desa Kiarasari, dan sebelah barat berbatasan dengan Desa Kiarapandak.

Kegiatan pengabdian dilakukan dengan tahapan sebagai berikut:

1. Persiapan.

Kegiatan persiapan mulai dari proses survei permasalahan yang ada pada desa mitra sampai dengan wawancara langsung dengan penduduk setempat.

2. Sosialisasi

Sosialisasi tentang Program Pengabdian Masyarakat dari Politeknik Negeri Jakarta kepada Desa Mitra tentang tujuan dan manfaat yang akan didapatkan.

3. Pelaksanaan Pekerjaan Fisik

Kegiatan pelaksanaan pembanguna bangunan MCK Umum.

4. Pengawasan dan penyusunan pelaporan

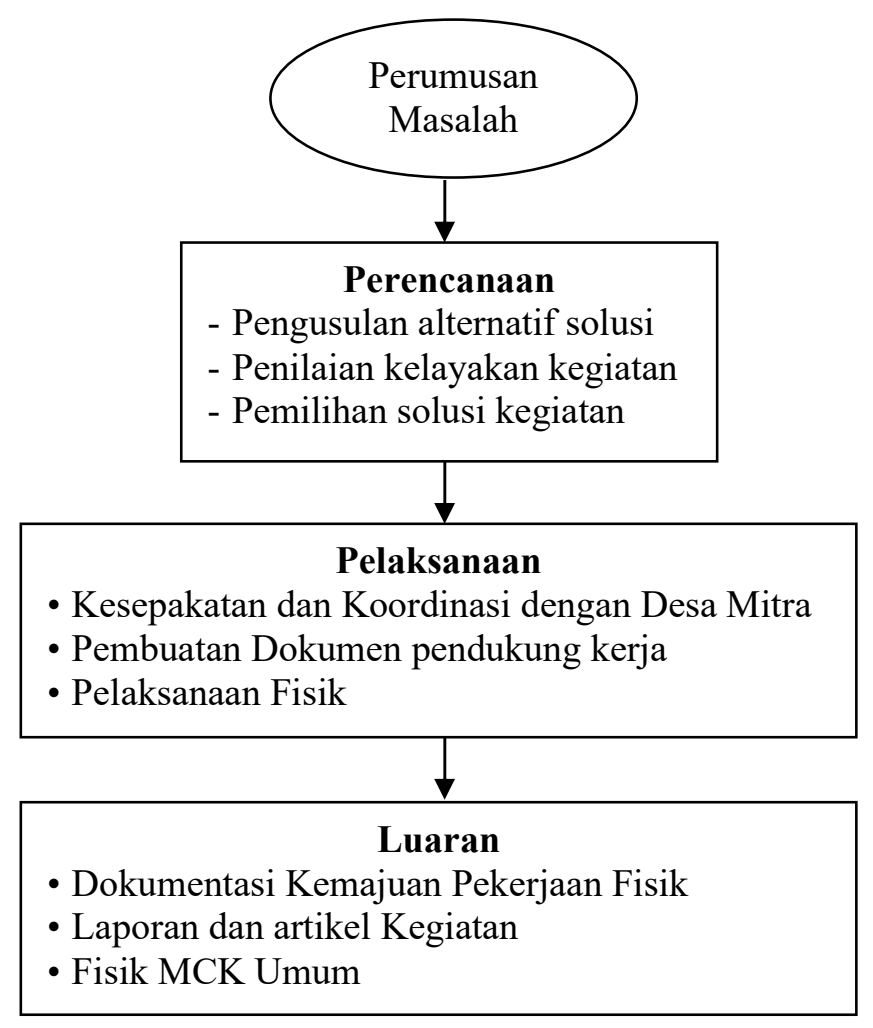

Gambar 1. Tahapan Pelaksanaan Kegiatan

Pemilihan lokasi dan Perhitungan kebutuhan MCK berdasarkan SNI 03-2399-2002. Lokasi dipilih berdekatan dengan area pelayanan dan berdekatan dengan badan air 
permukaan. Akses dengan jalan masyarakat mudah dicapai dan bukan di daerah yang mudah longsor atau rawan bencana. Jarak maksimal antara lokasi MCK umum dengan rumah penduduk yang dilayani adalah 100 meter. Lokasi daerah harus bebas banjir.

Gambar $2 \mathrm{a}$ dan $2 \mathrm{~b}$ menunjukkan area yang berdekatan dengan daerah sungai dan tersedia sumber air permukaan dari mata air yang dialirkan melalui pipa-pipa. Gambar $2 \mathrm{c}$ dan $2 \mathrm{~d}$ menggambarkan lokasi dekat dengan akses jalan masyarakat dan permukiman penduduk.

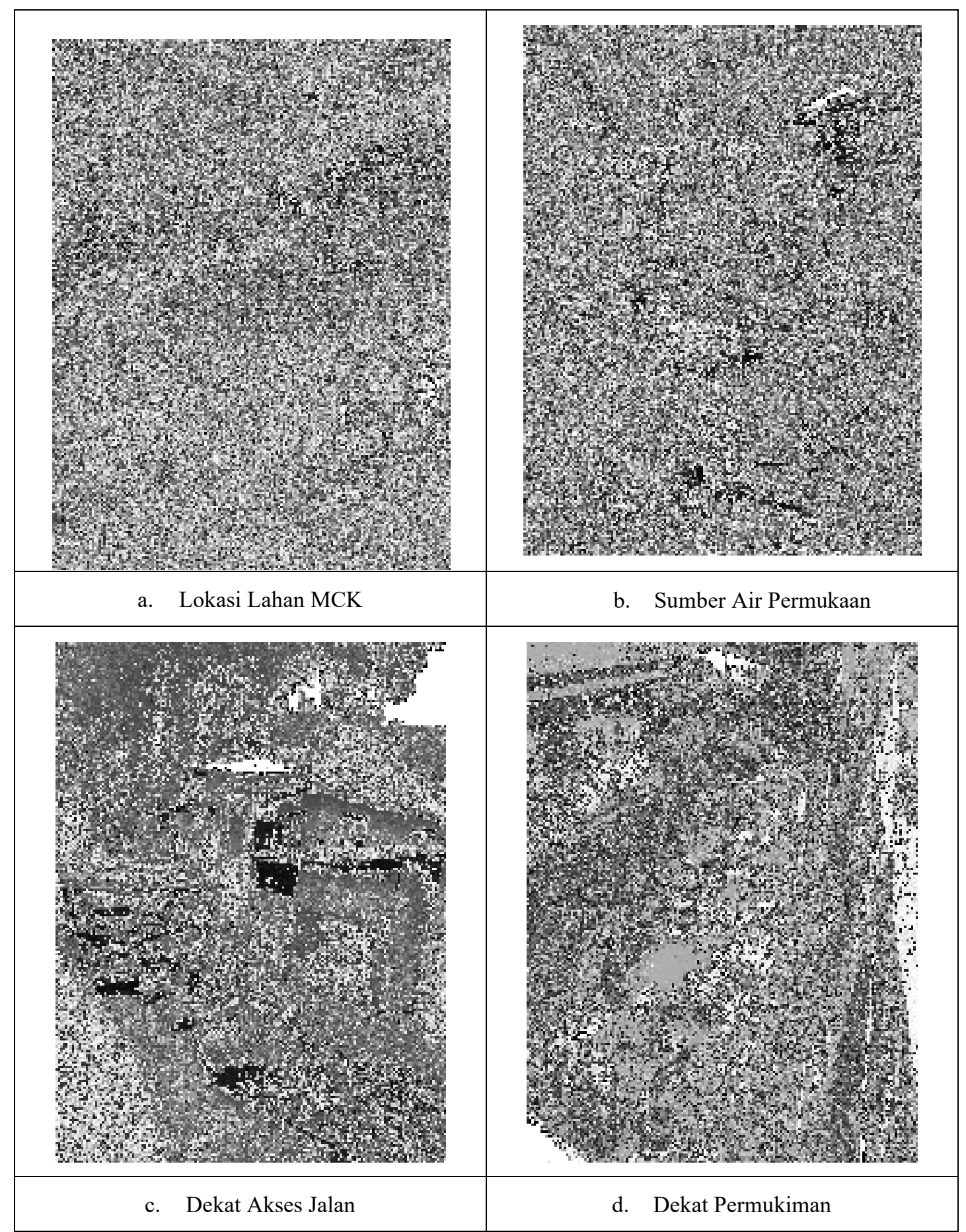

Gambar 2. Pemilihan Lokasi MCK Dekat Dengan Sumber Air Permukaan dan Jalan ke Permukiman 
Perhitungan kebutuhan MCK dan sanitasinya berdasarkan jumlah warga yang dilayani. Menurut SNI 03-2399-2002, satu MCK yang terdiri dari dua buah kamar mandi dengan dua kakus dan satu tempat cuci, dapat melayani sampai 20 orang. Akan tetapi pada pelaksanaan pengabdian ini perhitungan tersebut disesuaikan untuk 25 orang dengan pertimbangan kondisi Desa Urug yang cukup padat. Banyaknya ruangan mandi, cuci dan kakus dalam bentuk satu kesatuan bangunan MCK dan satu konstruksi atap. Gambar 3 di bawah ini mengilustrasikan MCK yang dibangun. MCK terdiri dari 2 kamar mandi yang disatukan dengan kakus dengan penutup atap satu. Luas bangunan utama MCK adalah $9 \mathrm{~m}^{2}$, ini belum termasuk dengan ruang cuci.

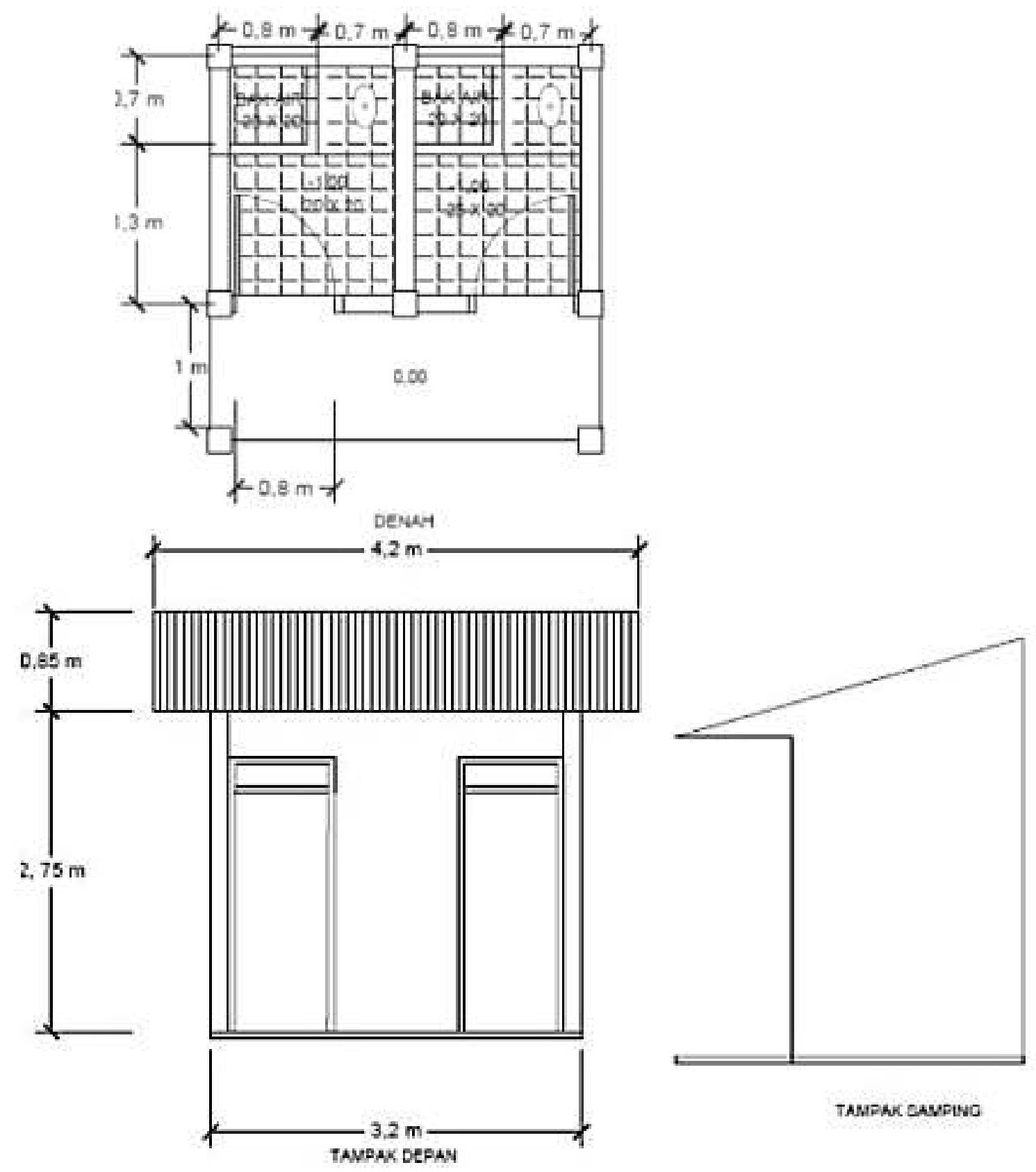

Gambar 3. Gambar Denah, Tampak Depan dan Tampak Samping MCK 
Material bangunan yang digunakan mempertimbangkan kemudahan pelaksanaan dengan mengambil bahan dari bahan bangunan setempat dan dapat diterima oleh masyarakat pemakai. Masyarakat Urug mempercayai bahwa untuk bahan atap tidak boleh menggunakan bahan dasar dari tanah karena penutup tanah tidak boleh untuk manusia yang masih hidup. Pondasi berbahan batu kali dan kolom-balok berbahan beton. Conblok digunakan sebagai dinding bangunan MCK dan bak sanitasi serta sumur resapan. Rangka atap dari kayu dan penutup atap menggunakan asbes. Gambar 4 menunjukkan material bangunan yang digunakan pada bangunan MCK.

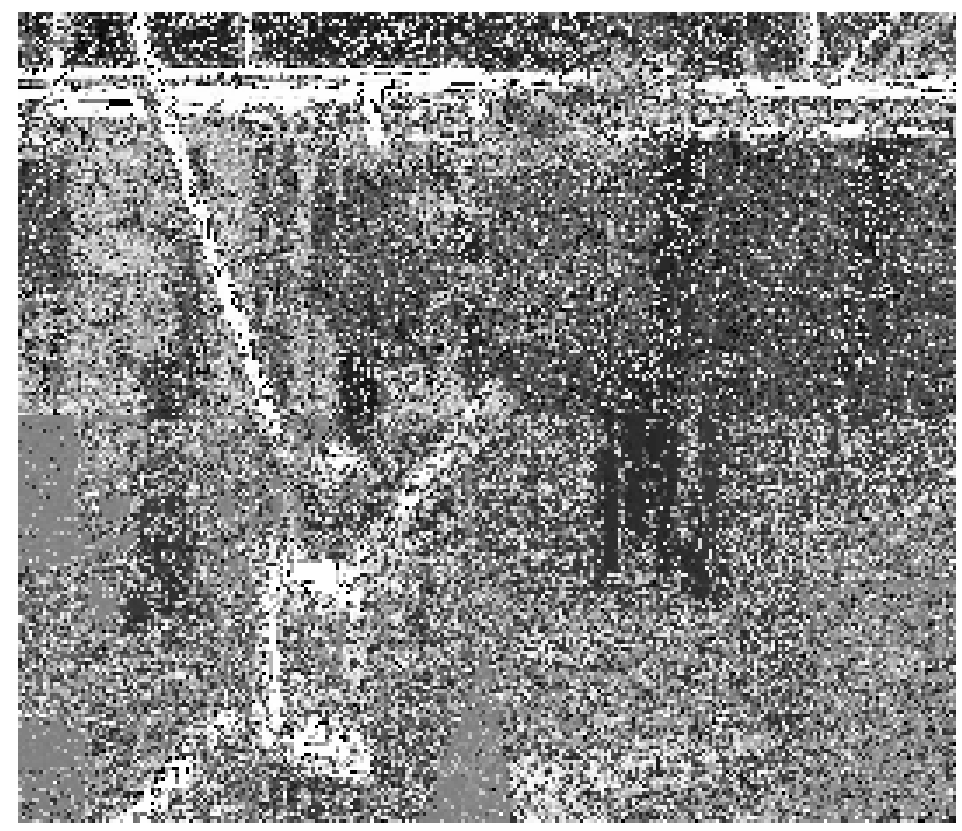

Gambar 4. Bahan Bangunan MCK

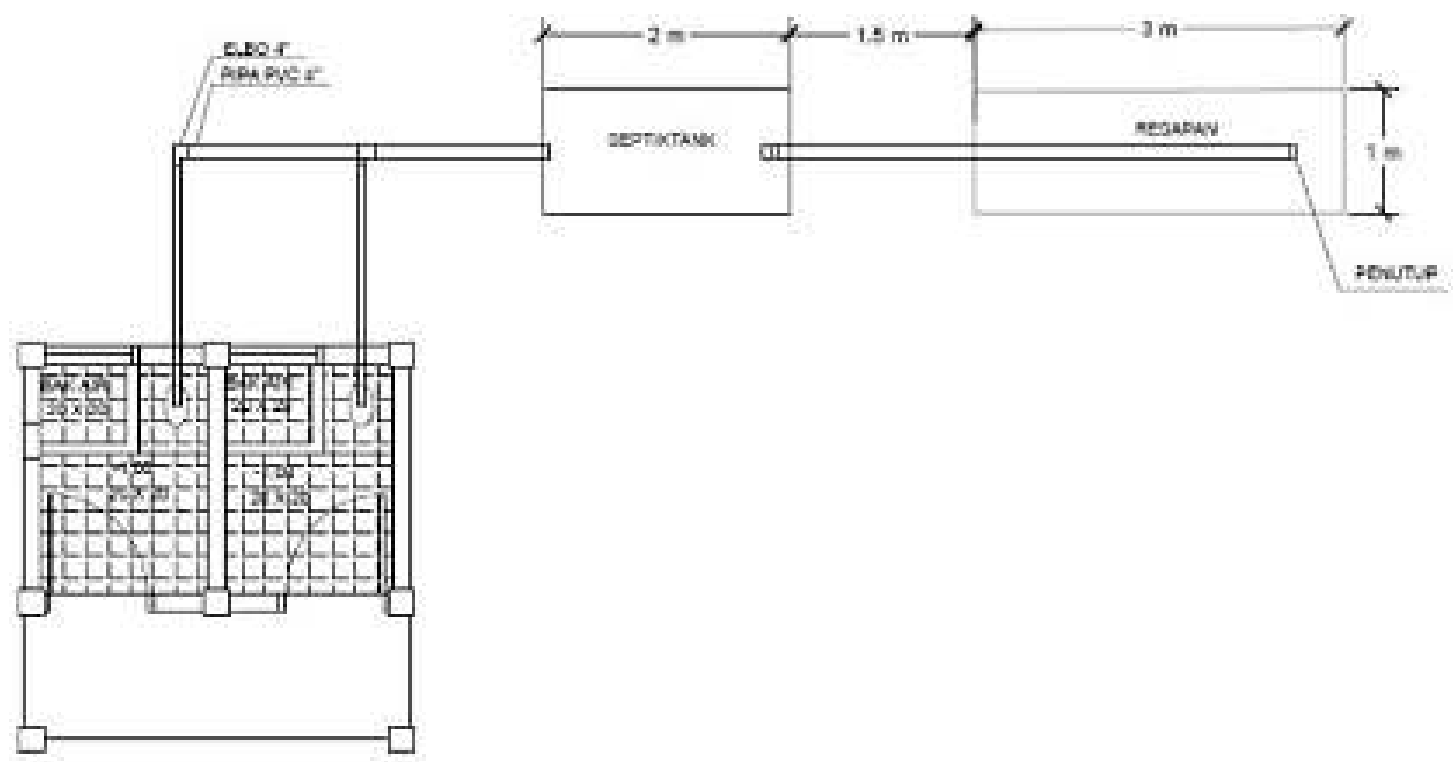

Gambar 5. Gambar Jaringan Sistem Pemipaan Sanitasi 
Mengenai jaringan sanitasi direncanakan dengan perhitungan kuantitas air yang disesuaikan untuk kesatuan MCK, yaitu: 20 Liter/orang/hari untuk mandi, 15 Liter/orang/hari untuk cuci, 10 Liter/orang/hari untuk kakus. Bagian dari sistem plambing yang terdiri dari pipa yang dipasang untuk sirkulasi udara ke seluruh bagian dari sistem pembuangan dan mencegah terjadinya kerja sifon dan tekanan balik pada perangkap. Bagian dari sistem plambing yang menyalurkan air hujan termasuk diantaranya adalah pipa air hujan dan pipa air tanah. Untuk air buangan kakus diarahkan langsung ke septiktank. Dari septiktank dibuat sumur resapan sekaligus sebagai pembuangan air hujan atap. Septiktank dan sumur resapan berada langsung di bawah bangunan MCK dengan bak yang terpisah dan kedap.

\section{Hasil dan Pembahasan}

Untuk memenuhi kriteria penginapan standard ASEAN (ASEAN homestay standard). Keberadaaan MCK Komunal dengan pencapaian yang mudah dari homestay sangat dibutuhkan. Fasilitas pelengkap yang memenuhi higienis untuk penyediaan makanminum dan kebersihan lingkungan untuk mendukung pemandangan wisata alam. Jumlah MCK dan sanitasi yang memenuhi jumlah kedatangan wisatawan pada waktu terpadat.

\section{Analisis Kondisi Lingkungan dan Kebersihan}

Desa urug mempertahankan $60 \%$ lahannya untuk pertanian sebagai mata pencaharian utama warganya. Hal ini cukup baik untuk daerah resapan air dan menjaga sumber daya air untuk daerah permukimannya. Namun sisa lahan yang tersedia untuk permukiman sangat padat dengan ukuran rumah sekitar $20-60 \mathrm{~m}^{2}$ yang saling berdekatan dengan jarak 1-2 meter. Akses jalan adalah gang yang berukuran 1-3 meter sehingga hanya nyaman dilalui kendaraan roda 2 . Bentuk lahan yang berkontur dengan persentase lereng sampai $50^{\circ}$ membutuhkan pengaliran drainase yang baik agar tidak menjadi genangan yang mengganggu akses kendaraan.

Kepadatan penduduk mempengaruhi kebersihan sungai karena kebiasaan turun-temurun menggunakan sungai sebagai pembuangan akhir. Kondisi saat ini sungai kering dan mulai ditemui sampah dan sedikit tercemar. Kebiasaan warga mandi, mencuci, dan membuang hajat langsung di sungai perlu diperbaiki. Walaupun beberapa MCK mulai terbangun, kebiasaan ini belum tentu dapat dihilangkan. Hal ini diperparah dengan mata air yang tidak mencukupi kebutuhan warga dan perkebunan sawit terdekat yang menyerap air tanah lebih besar. Warga kekurangan sumber air bersih sehingga sebagian warga menggunakan air sungai yang mulai tercemar. Kondisi ini dapat menimbulkan potensi penyakit dan mempengaruhi kesehatan warga. Selain itu kualitas daya dukung sungai yang menurun dapat mengurangi minat destinasi wisata.

\section{Analisis Potensi Pemeliharaan Sanitasi Komunal Masyarakat dan Wisata}

Kelembagaan desa sudah memulai gerakan untuk mengatasi persoalan kebutuhan higienis warga dan mempertahankan kebersihan lingkungan dengan program pemilahan sampah dan sosialisasi kepada warga. Warga juga sudah mulai menggunakan MCK yang terbangun namun masih ada sebagian warga yang melakukan aktifitas di sungai dekat MCK. Ini perlu waktu dan sosialisasi untuk memperbaiki perilaku warga agar mau menggunakan MCK.

Tingkat pendidikan warga masih cukup rendah 50\% lulusan sekolah dasar, $42 \%$ setara sekolah menengah dan sisanya diploma/sarjana. Akan tetapi warga cukup patuh kepada 
ketua adat sehingga ketua adat dan perangkatnya dapat berperan dalam meningkatkan perilaku kebersihan warga. Aparat pemerintahan desa cukup responsif dalam upaya mengatasi masalah kesehatan dan kebersihan warganya namun membutuhkan dukungan tenaga ahli dan nara sumber untuk memecahkan masalah yang lebih teknis. Masalah teknis yang dihadapi seperti teknis pemetaan lokasi, perencanaan drainase, pengadaan sumber air bersih, perbaikan arsitektur homestay, pemeliharaan bangunan heritage, manajemen kawasan wisata, dan sosialisasi kesehatan lingkungan kepada warga.

\section{Analisis MCK Komunal sebagai Instrumen Pendukung Cultural Heritage}

MCK komunal yang berada di sekitar permukiman warga, perlu mendapatkan citra yang baik sebagai elemen wisata. Pemahaman budaya tentang MCK sebagai bagian pelengkap yang berada di belakang menyebabkan kurangnya perencanaan yang menarik. Sebaliknya sebagai pelengkap daerah wisata, MCK komunal harus selalu bersih dan menarik. Ini adalah gap yang membutuhkan diskusi lebih lanjut antara perencana, aparat, perwakilan warga dan ketua adat. MCK yang sudah terbangun masih terlalu sederhana dan belum terlihat sebagai elemen penting dalam wisata desa.

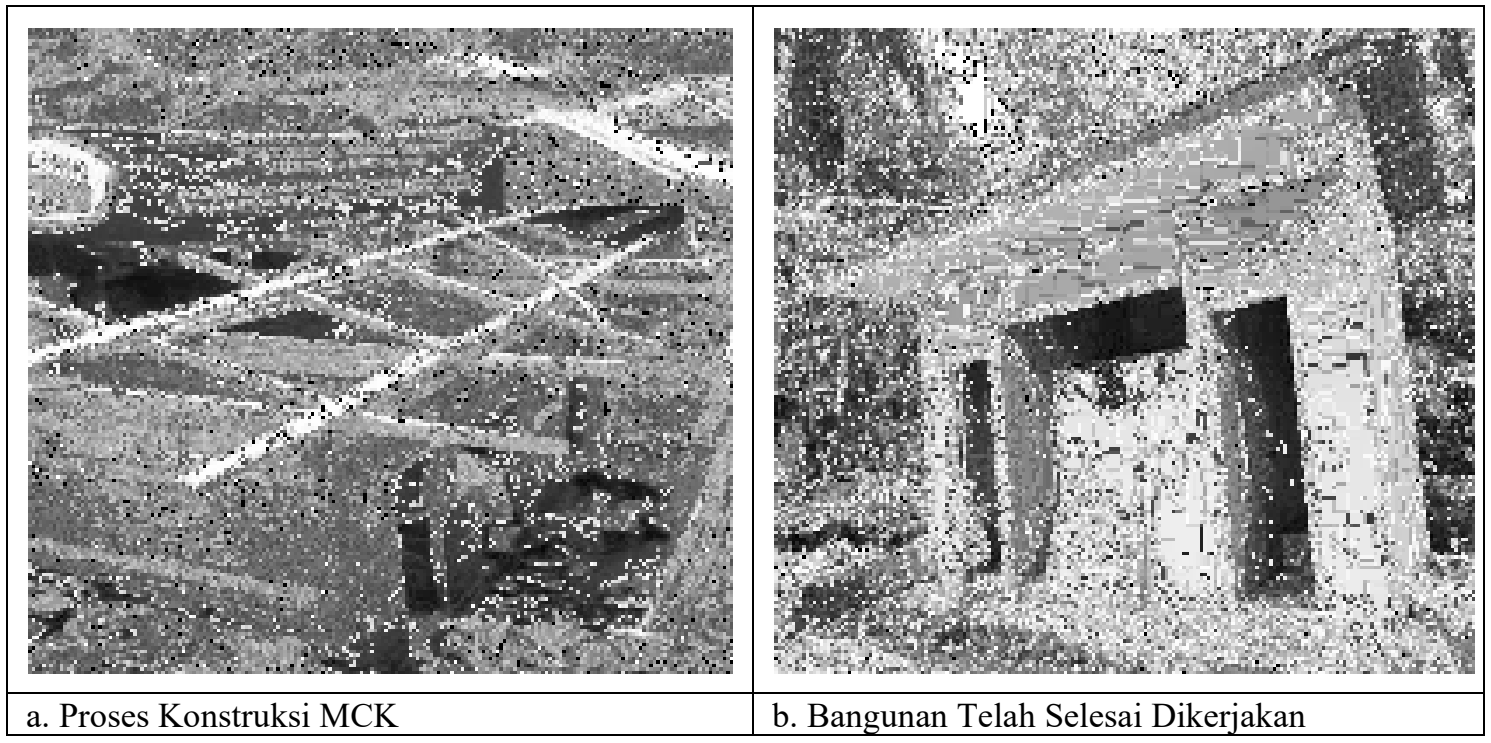

Gambar 6. Gambar Proses Konstruksi MCK dan Bangunan Telah digunakan Warga

Gambar 6 menunjukkan MCK komunal yang dilaksanakan dalam pengabdian ini. MCK komunal tersebut sudah sesuai dengan kebutuhan warga dengan dilengkapinya sanitasi dan tidak melanggar aturan adat. Akan tetapi untuk meningkatkan fungsinya juga sebagai elemen wisata, masyarakat perlu secara bergotong royong menata taman di sekitar MCK komunal. Dengan demikian biaya yang dibutuhkan tidak besar dan terlihat lebih nyaman dan menarik untuk wisatawan.

Berdasarkan analisis tersebut, pembangunan MCK komunal sangat penting sebagai proyek awal peningkatan kualitas kawasan wisata Desa Urug. Menurut satu penelitian, hubungan yang signifikan antara pengetahuan masyarakat dengan pemanfaatan MCK komunal, tidak ada hubungan antara tingkat pendidikan, penghasilan dan sikap masyarakat dengan perilaku pemanfaatan MCK Komunal (Wirawan, 2017). Hasil pengabdian ini sedikit berbeda karena dari hasil observasi perilaku higienis warga terjadi karena keterbatasan pengetahuan warga dan sebagian besar warga kurang 
berpendidikan. Kemiskinan warga juga memicu ketidakmampuan untuk membangun MCK pribadi sehingga beralih ke sungai. Setelah MCK terbangun sebagian besar warga memilih untuk beralih dari sungai walaupun masih ada sebagian warga terutama yang berusia di atas setengah baya ( $>50$ tahun) yang masih menggunakan sungai.

Selain pembangunan MCK komunal secara fisik, pengawasan dan ketahanan kemampuan warga memeliharanya sangat dibutuhkan. Kerja sama antara Pemda setempat untuk melakukan pengamanan kawasan diperlukan untuk mencegah perubahan lahan dapat menyebabkan perubahan fisik kawasan desa (Dian, 2018). Untuk meningkatkan kepedulian warga salah satu cara adalah dengan membayar dengan biaya terjangkau dan biaya pemeliharaan secara mandiri. Penelitian sebelumnya menyatakan memberdayakan penyedia layanan untuk menetapkan dan mengumpulkan tarif yang terjangkau dan adil sangat penting bagi semua pendekatan untuk pemulihan biaya (CSG, 2016). Ini dapat sebagai titik awal dapat memberdayakan penyedia layanan untuk meningkatkan pendapatan yang diperlukan untuk layanan lokal dan pemeliharaan layanan yang lebih luas.

Dalam pembahasan ini, berkaitan dengan pembangunan yang berkelanjutan yang membutuhkan keseimbangan pembangunan antar dimensi sosial, dimensi lingkungan, dan ekonomi (Miller, 2012). Gambar 7 mengilustrasikan kepentingan pembangunan MCK dan sanitasi kepada keberlanjutan kawasan wisata. Dalam dimensi sosial dapat meningkatkan perilaku higienis warga. Dalam dimensi lingkungan dapat mempertahankan kebersihan sungai. Selanjutnya dalam dimensi ekonomi dapat menambah daya tarik wisata yang berimolikasi kepada kesejahteraan masyarakat.

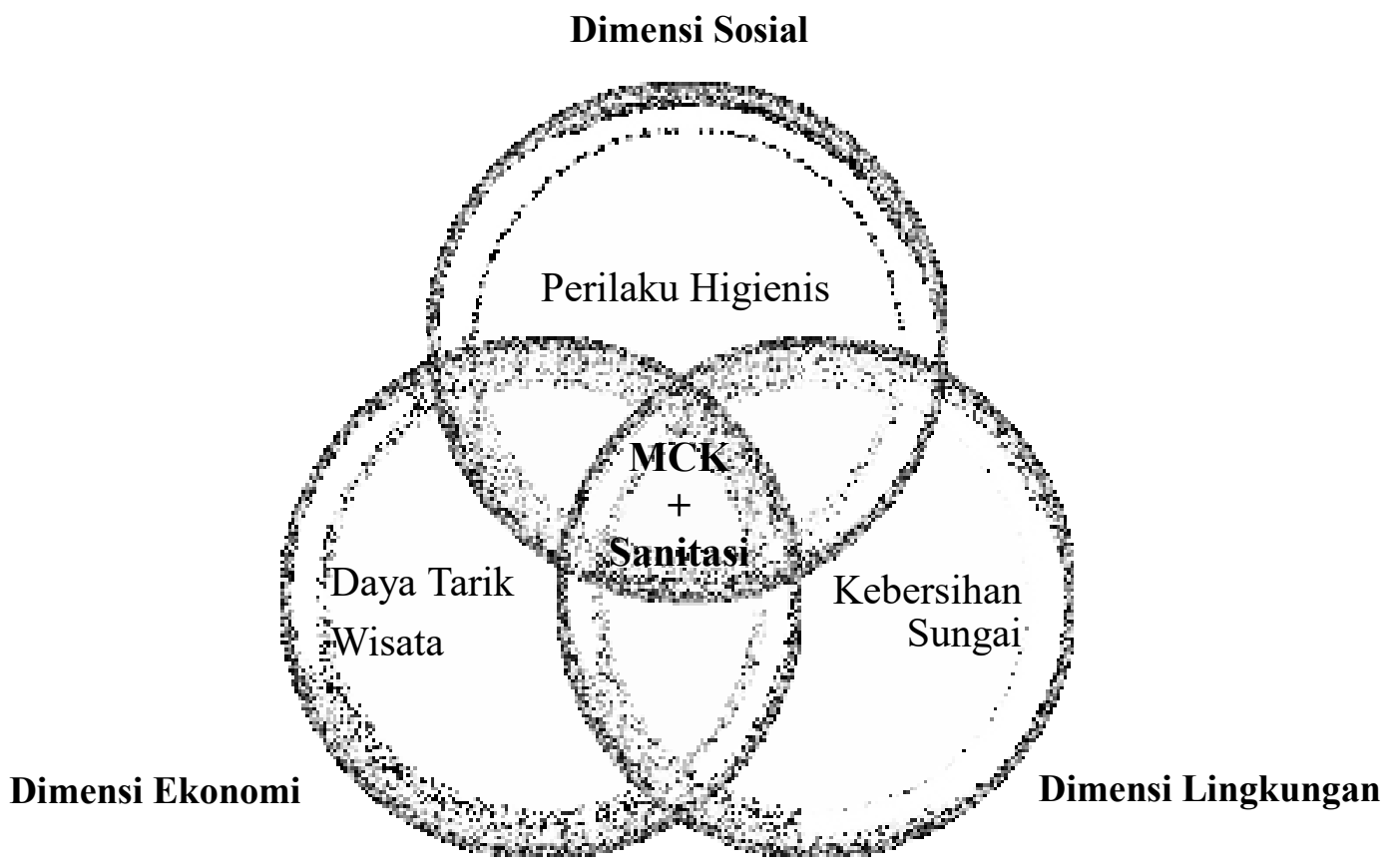

Gambar 7. Model Konseptual MCK dan Sanitasi Dalam Konsep Pembangunan Keberlanjutan 


\section{Kesimpulan}

Hasil pengabdian ini menunjukkan program MCK komunal di kawasan wisata heritage Desa Urug dapat meningkatkan destinasi wisata kawasan bila dilakukan pengawasan dan pemeliharaan yang melibatkan masyarakat. Peran aparat mengupayakan ketersediaan MCK komunal mendorong masyarakat berperilaku higienis dan mempertahankan fungsi sungai. Beberapa pendekatan untuk mempertahankan kebersihan MCK komunal adalah melibatkan masyarakat pengguna, salah satunya dengan partisipasi tarif yang terjangkau.

\section{Saran}

Untuk memperlancar kegiatan ini, diperlukan partisipasi mitra, yaitu warga bersamasama tim pengabdian bergotong royong dalam melaksanakan Pembangunan MCK Umum. Kedua lembaga penyandang dana lainnya untuk menyediakan air dan listrik pada saat berlangsungnya kegiatan. Kendala yang dihadapi pada saat pelaksanaan pembangunan MCK komunal adalah mobilisasi suplai material karena akses jalan yang sempit sehingga membutuhkan waktu pemindahan yang lebih lama.

\section{Ucapan Terima kasih}

Pengabdian ini dibiayai DIPA Politeknik Negeri Jakarta Pengabdian Masyarakat Berbasis Jurusan Nomor kontrak: 729/PL3.18/PN.01/2018, tanggal 8 Juni 2018.

\section{Daftar Pustaka}

ASEAN Secretariat. 2016. ASEAN Homestay Standard. ISBN 978-602-0980-74-4.

Community Sanitation Governance (CSG). 2016. A Riview and Comparative Analysis if Indicative Service Costs for Different Sanitation Service Scales in Indonesia. Institute for Sustainable Futures. 1-25.

Dian, M.P. dan Nazir, I.R. 2018. Dampak Model Pengembangan Wisata Budaya Terhadap Upaya Pelestarian di Kampung Naga, Garut, Indonesia. Saintech, 28(2). 1521. ISSN: 1410-7104.

Fachrudin, H.T. dan Lubis, M.D. 2016. Planning for Riverside Area as Water Tourism Destination to Improve Quality of Life Local Residents, Case Study: Batuan-Sikambing River, Medan, Indonesia. Procedia-Social and Behavioral Sciences. 234. 434-441.

Heston, Y.P. dan Ayuningtyas, Y.R.. 2007. Water and Sanitation Technology Citizen Needs Assessment in Kolorai Island. IOP Science. 152. DOI: 10.1088/17551315/152/1/012007.

Miller, G.T., Spoolman, S.E. 2012. Living in The Environment. Brooks/Cole. USA.

Nurwidyaningrum, D. 2014. Potensi Konservasi Energi Rumah Tinggal di Permukiman Perkotaan Berbasis Budaya Masyarakat Sunda. Tesa Arsitektur, Journal of Architectural Discourses. 12(1). 28-42.

Peraturan Menteri Pekerjaan Umum dan Perumahan Rakyat Republik Indonesia (PERMENPUPR RI). 2017. Penyelenggaraan Sistem Pengelolaan Air Limbah Domestik. Nomor 04/PRT/M/2017. 
Pratminingsih, S.A., Rudatin, C.L., T.Rimenta. 2014. Role of Motivation and Destination Image in Predicting Tourist Revisit Intenstion: A Case of bandungIndonesia. International Journal of Innovation, Management and Technology. 5(1). 1924.

Standar Nasional Indonesia (SNI). 2002. Tata Cara Perencanaan Bangunan MCK Umum. SNI 03-2399-2002. ICS 27.180. Badan Standardisasi Nasional.

Wirawan, P., Razak, A., Dewata, I. 2017. Hubungan Pendidikan, Penghasilan, Pengetahuan dan Sikap Masyarakat dengan Pemanfaatan MCK Komunal. Promotif Jurnal Kesehatan Masyarakat. 7(2). 135-145. ISSN 2503-1139. 